\title{
NONSPECIFIC PROTEASE AND ELASTASE ACTIVITIES IN RAT LEUKOCYTES ${ }^{1}$
}

\author{
J. VARANI, D. WARD, and K. J. JOHNSON \\ Department of Pathology \\ University of Michigan Medical School \\ Ann Arbor, Michigan 48109
}

\begin{abstract}
Extracts were prepared from rat peritoneal leukocytes obtained $4 \mathrm{~h}$ after glycogen injection and assayed for proteolytic enzyme activities against various substrates. The substrates used included acid-denatured bovine hemoglobin, bovine serum albumin, a partially purified preparation of rat pulmonary basement membrane, bovine neck ligament elastin, and an artificial substrate with elastase specificity. A high level of activity was observed when hemoglobin was used as the substrate. The serum albumin and basement membrane preparation were also readily hydrolyzed by the leukocyte extract. In contrast, the native elastin and synthetic elastase substrate were much more resistant. Although the leukocyte extract demonstrated little intrinsic elastase activity, when it was mixed with a commercial hog pancreatic elastase preparation, it greatly potentiated the elastolytic activity, suggesting the activation of a latent enzyme.
\end{abstract}

\section{INTRODUCTION}

Human polymorphonuclear leukocytes contain at least three distinct neutral proteases: elastase, chymotrypsin, and collagenase (1-6). Analogous enzymes have been identified in the leukocytes of several other species, but it is apparent that considerable species-dependent differences exist (7-12). These differences may be critical to the species differences in susceptibility to various pathological processes. In this report we describe the neutral protease activity obtained from rat granulocytes. The rat granulocytes have a high level of neutral protease activity when measured against a variety of substrates. However, when native elastin or a synthetic elastase substrate are used as substrates, very little activity is detected.

\footnotetext{
${ }^{1}$ This study was supported in part by NIH grants CA29550, CA29551, and HL00889.
} 


\section{MATERIALS AND METHODS}

Preparation of Rat Leukocyte Extracts. Extracts were prepared from the pooled, peritoneal leukocytes obtained from Sprague-Dawley rats (Charles Rivers) 4-6 h after intraperitoneal injection of $0.1 \%$ glycogen in phosphate-buffered saline (13). Normally five to six $600-\mathrm{g}$ rats were used for each preparation. After combining the cells and hypotonically lysing the red blood cells (if necessary), the remaining cells, which consisted of $96-98 \%$ granulocytes were resuspended in $6-8 \mathrm{ml}$ of saline containing $0.05 \mathrm{M}$ phosphate buffer at $\mathrm{pH} 7.4$ and subjected to homogenization and three cycles of freeze-thawing. Following this, the particulate fraction was removed by centrifugation, and the supernatant fluid was divided into $1-\mathrm{ml}$ portions and frozen at $-70^{\circ} \mathrm{C}$ until use. From 5-6 rats $2.5-5 \times 10^{8}$ leukocytes were obtained. The extracts prepared from this number of cells contained approximately $50 \mathrm{mg}$ of protein when assayed by the Folin method with bovine serum albumin as the standard.

For certain experiments the lysosomal granules were prepared from the harvested cells. The cells were homogenized in $0.34 \mathrm{M}$ sucrose and the granule fraction separated by differential centrifugation (14).

Extracts prepared from human granulocytes were used for comparison. The cells were obtained from leukocyte phoresis donors through the courtesy of the Connecticut Red Cross. Whole-cell extracts were prepared from the human cells in the exact same manner as from the rat cells.

Protease Assays. In these experiments we routinely measured hemoglobin-hydrolyzing activity (which we define as nonspecific protease activity) and elastase activity. Hemoglobin hydrolytic activity was quantitated using a highly-sensitive, solid-phase assay developed by us previously $(15,16)$. In this procedure acid-denatured bovine hemoglobin (Sigma Chemical Co., St. Louis, Missouri) is labeled with ${ }^{125} I$. The labeled substrate is diluted with unlabeled hemoglobin, and $10 \mu \mathrm{g}$ of the material is dried onto the bottom of microtiter wells (96-well tissue culture plates from Costar, Cambridge, Massachusetts). To run the test, $200 \mu$ l of the test solution is added to each well and incubated at $37^{\circ} \mathrm{C}$ for $1 \mathrm{~h}$. Following this, $100 \mu \mathrm{l}$ is withdrawn and counted in a gamma counter for ${ }^{125} \mathrm{I}$. Quadruplicate wells are used per test. Trypsin (type IS; $2 \times$ crystallized from bovine pancreas; Sigma Chemical Company) is routinely used as a standard. In our previous study describing the solid-phase protease assay, we demonstrated that nearly all of the released ${ }^{125} I$ was associated with $10 \%$ trichloracetic acid-soluble fragments. Likewise, we demonstrated that trypsin-induced solubilization was prevented by protease inhibitors which also blocked activity in a conventional protease assay (15).

Although hemoglobin was the protein substrate routinely used, we also tested the ability of the rat granulocyte protease to hydrolyze commercially prepared bovine serum albumin (Sigma Chemical Company) and bovine fibrinogen (Pentex Biochemical Co., Kankakee, Illinois) and to hydrolyze a partially purified rat pulmonary basement membrane preparation (17). Each protein was labeled with ${ }^{125} \mathrm{I}$ and treated in exactly the same way as the hemoglobin.

Two methods were used to assess elastase activity. One was a standard colorimetric assay using $N$-succinyl-alanyl-alanyl-alanine- $p$-nitroanilide as the substrate (18). The substrate was obtained from Bachem, Inc. (Torrance, California). In the second method, $\left[{ }^{14} \mathrm{C}\right]$ elastin was used as the substrate. The labeled elastin was kindly supplied by Dr. Robert Senior (Department of Pathology, Jewish Hospital, St. Louis, Missouri). The elastin hydrolytic activity was determined in a standard fluid phase assay as described previously (15). Elastase (type I, 2X crystallized from hog pancreas; Sigma Chemical Co.) served as a standard in the elastase assays.

A number of protease inhibitors were used in this study. These included soybean trypsin inhibitor (SBTI) (type IS), lima bean trypsin inhibitor (LBTI) (type IIL), $N-\alpha-p$-tosyl-1-lysine chloromethyl ketone (TLCK), L-1-tosylamide-2-phenylethyl chloromethyl ketone (TPCK), leupeptin, and pepstatin A. All were purchased from Sigma Chemical Company. 


\section{RESULTS}

Protease Activity in Rat Leukocyte Extracts. Peritoneal leukocytes were harvested from groups of 5-6 Sprague-Dawley rats $4 \mathrm{~h}$ after glycogen injection. The leukocytes were pooled, and whole-cell extracts were prepared as described in the Materials and Methods section. The extracts were then analyzed for protease activity using $\left[{ }^{[25} \mathrm{I}\right]$ hemoglobin as the substrate in a highly sensitive solid-phase assay (15). Trypsin was used as a standard enzyme preparation. It can be seen in panel A of Figure 1 that $60 \mu \mathrm{g}$ of leukocyte extract had hemoglobin-hydrolyzing activity equivalent to approximately $0.8 \mu \mathrm{g}$ of the crystallized trypsin preparation.

In addition to hemoglobin-hydrolyzing activity, we also examined the ability of the extract protease to hydrolyze bovine albumin, bovine fibrinogen, and a partially purified rat pulmonary basement membrane preparation. All three substrates were readily hydrolyzed by the extract preparam tions (data not shown).

We next examined the rat leukocyte extract preparations for elastase activity. Both the synthetic substrate, succinyl-alanyl-alanyl-alanine-pnitroanilide and bovine neck ligament elastin were used as substrates. Commercially available hog pancreatic elastase was used as a control enzyme preparation for these studies. The results shown in panel B of Figure 1 and in Table 1 indicate that there was very little detectable elastase activity in the granulocyte extracts. Sixty micrograms of extract protein gave a barely detectable response when assayed using the artificial substrate. To obtain measurable activity with this substrate, we had to use 10 times that amount of protein. Likewise, when native elastin was used as the substrate, $60 \mu \mathrm{g}$
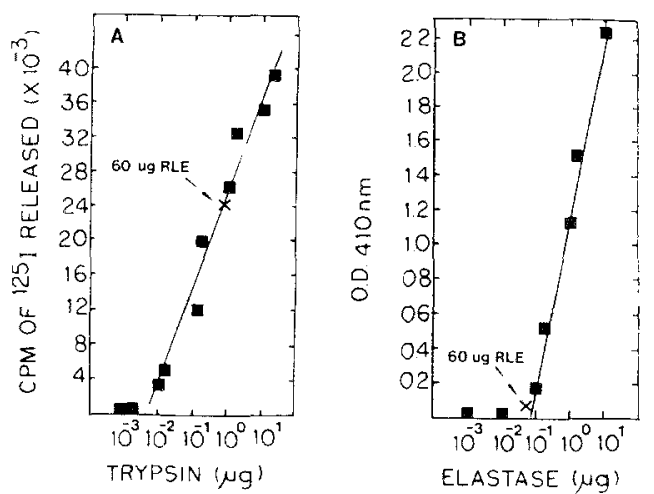

Fig. 1. Hemoglobin-hydrolysis activity and elastase activity in the rat leukocyte extract (RLE). The standard curves were generated as described in the Materials and Methods section. Trypsin (crystalized from bovine pancreas) was used in the hemoglobin-hydrolysis assay (panel A) and hog pancreatic elastase (crystalized) was used in the elastase assay (panel B). 
Table 1. Elastase Activity in Rat Leukocyte Extracts ${ }^{a}$

\begin{tabular}{lc}
\hline \multicolumn{1}{c}{ Enzyme preparation ${ }^{b}$} & $\begin{array}{c}\text { Activity (cpm } \pm S E M \text { of } \\
{ }^{14} \text { C released from bovine } \\
\text { neck ligament elastin) }\end{array}$ \\
\hline Saline & $207 \pm 31$ \\
Trypsin & $219 \pm 14$ \\
Hog pancreatic elastase & $2110 \pm 180$ \\
Rat leukocyte extract & $514 \pm 15$ \\
Human leukocyte extract & $1814 \pm 101$ \\
\hline
\end{tabular}

${ }^{a}$ See the Materials and Methods section for details of the assay.

${ }^{b}$ The enzyme preparations consisted of the following: trypsin (10 $\mu \mathrm{g}$ of crystalized bovine pancreas trypsin); elastase (1 $\mu \mathrm{g}$ of hog pancreatic elastase); rat leukocyte extract $(60 \mu \mathrm{g}$ of protein), and human leukocyte extract (amount of extract equivalent to $0.8 \mu \mathrm{g}$ of trypsin in hemoglobin-hydrolytic activity.

of extract protein demonstrated only slightly more activity than either trypsin or the control buffer alone. In contrast the commercially available elastase readily hydrolyzed the elastin substrate (Table 1). For comparison purposes, a human peripheral blood leukocyte extract was prepared and normalized to the rat leukocyte extract with regard to hemoglobin-hydrolyzing activity. In contrast to the rat leukocyte extract, the human leukocyte extract demonstrated high levels of elastolytic activity. This was not surprising since human leukocytes are known to contain a large amount of elastase $(2,3)$.

In addition to measuring hemoglobin-hydrolyzing activity and elastinhydrolyzing activity in whole-cell extracts, we also examined lysosomal granule preparations for the same activities. The results obtained with the lysosomal granules were very similar to the results obtained using the wholecell extracts. That is, we obtained a high level of protease (hemoglobin hydrolyzing) activity under conditions in which very little detectable elastase activity was found (data not shown).

Characteristics of Protease Activity in Rat Leukocyte Extract Preparations. Some of the characteristics of the rat granulocyte neutral protease are shown in Figures 2 and 3 and in Table 2. In Figure 2 (panel A), it can be seen that hemoglobin-hydrolyzing activity is linear over a 100 -fold range. Detectable activity could be seen when as little as $0.6 \mu \mathrm{g}$ of protein were used. In panel B of Figure 2 it can be seen that activity was measurable over a pH range of 4.0-8.0. Maximal activity was observed at $\mathrm{pH} 8.0$.

Since measurable elastase activity was observed only at the highest concentrations of extract used, it was not possible to determine the range of linearity for the activity. We did, however, determine the optimal $\mathrm{pH}$ 

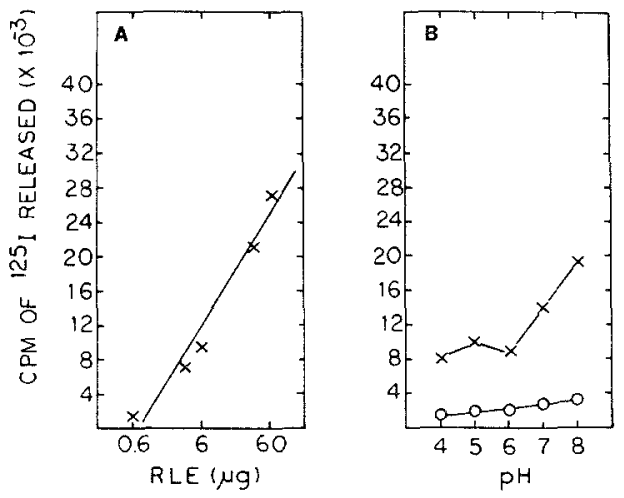

Fig. 2. Characteristics of the hemoglobin-hydrolysis activity in the rat leukocyte extract. Panel A shows the dose-response curve of the extract at $\mathrm{pH}$ 7.4. In panel $\mathrm{B}$ is shown the $\mathrm{pH}$ profile of the activity. Thirty micrograms of extract were used at each $\mathrm{pH}$. Assays at $\mathrm{pH} 4$ and 5 were run in $0.05 \mathrm{M}$ acetate buffer; assays at $\mathrm{pH} 6,7$, and 8 were run with $0.05 \mathrm{M}$ Tris $\mathrm{HCl}$ buffer $(\mathrm{O}-\mathrm{O}$, saline; $\mathbf{x}-\mathbf{x}$, rat leukocyte extract).

for elastase activity using the synthetic ester substrate. As with the hemoglobin-hydrolyzing activity, the maximum response was observed at $\mathrm{pH} 8.0$ (Figure 3). Unlike the hemoglobin-hydrolyzing activity, very little elastase activity was detected below $\mathrm{pH} 7$.

Table 2 shows the sensitivity of both the hemoglobin-hydrolyzing activity and the elastase activity (measured with the synthetic substrate) to

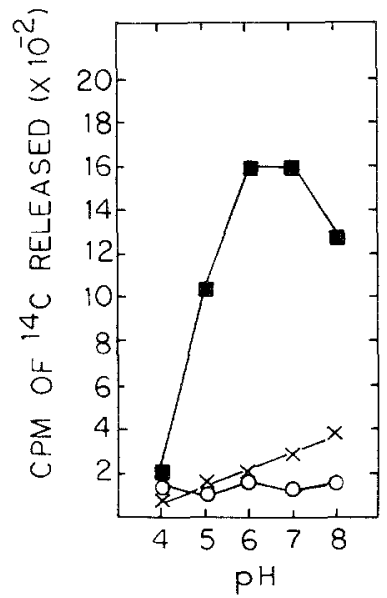

Fig. 3. The pH profile of rat leukocyte extract elastase activity. The assay was carried out using the $\left[{ }^{14} \mathrm{C}\right]$ bovine neck ligament elastin as the substrate. Assays at $\mathrm{pH} 4$ and 5 were run in $0.05 \mathrm{M}$ acetate buffer; assays at $\mathrm{pH} 6,7$, and 8 were run with $0.05 \mathrm{M}$ Tris $\mathrm{HCl}$ buffer $(\mathbf{G}$, hog pancreatic elastase; $\mathrm{O}-\mathrm{O}$, saline; $\boldsymbol{x}-\boldsymbol{x}$, rat leukocyte extract). 
Table 2. Inhibition of Rat Leukocyte Extract HemoglobinHydrolyzing Activity and Elastase Activity

\begin{tabular}{|c|c|c|}
\hline \multirow[b]{2}{*}{ Inhibitor } & \multicolumn{2}{|c|}{$\begin{array}{l}\text { Percent inhibition of } \\
\text { activity }( \pm S E M)\end{array}$} \\
\hline & $\begin{array}{l}\text { Hemoglobin } \\
\text { hydrolysis }^{a}\end{array}$ & Elastase $^{b}$ \\
\hline SBTI $(100 \mu \mathrm{g})$ & $84 \pm 5$ & $78 \pm 4$ \\
\hline LBTI $(100 \mu \mathrm{g})$ & $33 \pm 3$ & $67 \pm 4$ \\
\hline $\operatorname{TLCK}\left(5 \times 10^{-3} \mathrm{M}\right)$ & $25 \pm 2$ & $-15 \pm 3$ \\
\hline $\operatorname{TPCK}\left(5 \times 10^{-3} \mathrm{M}\right)$ & $47 \pm 3$ & $45 \pm 4$ \\
\hline Leupeptin $(25 \mu \mathrm{g})$ & $14 \pm 3$ & $-4 \pm 1$ \\
\hline Pepstatin $(25 \mu \mathrm{g})$ & $22 \pm 2$ & $-1 \pm 1$ \\
\hline \multicolumn{3}{|c|}{$\begin{array}{l}{ }^{a} \text { For the hemoglobin-hydrolysis assay } 250 \mu \mathrm{l} \text { of the rat leuko- } \\
\text { cyte extract }(1.5 \mathrm{mg} \text { of protein) was mixed with } 250 \mu \mathrm{l} \text { of the } \\
\text { inhibitor solution and incubated for } 30 \mathrm{~min} \text { at } 37^{\circ} \mathrm{C} \text {. Follow- } \\
\text { ing this, } 200 \mu \mathrm{l} \text { from this mixture was added to each substrate } \\
\text { well. The assay was then run in the normal way. } \\
{ }^{b} \text { For the elastase assay } 100 \mu 1 \text { of extract }(600 \mu \mathrm{g} \text { of protein) was } \\
\text { mixed with } 100 \mu \mathrm{l} \text { of the inhibitor solution and incubated for } \\
30 \text { min at } 37^{\circ} \mathrm{C} \text {. Three hundred microliters of buffer (with } \\
\text { substrate) was added to this mixture and the elastase assay } \\
\text { run in the normal way. }\end{array}$} \\
\hline
\end{tabular}

various protease inhibitors. Both the nonspecific protease activity and the elastase activity were susceptible to SBTI, LBTI, and TPCK. In contrast, TLCK, leupeptin, and pepstatin were much less effective against both. Only minimal inhibition was observed in the hemoglobin-hydrolysis assay, and no inhibition was seen in the elastase assay.

Activation of Latent Elastase by Rat Leukocyte Extract Preparations. Since we obtained a large amount of hemoglobin-hydrolyzing activity but very little elastase activity in the whole-cell extracts, we wanted to determine if an elastase inhibitor might be present in these preparations. To test for inhibitors, we mixed various quantities of the leukocyte extract preparations with known amounts of the standard hog pancreatic elastase and then tested for residual activity. We were surprised to find that not only was there no detectable inhibitory activity but rather, there was a tremendous potentiation of elastase activity. This finding suggested that there was either a latent elastase present in the leukocyte extract which could be activated by low levels of the hog pancreatic elastase or that there was latent elastase in the commercial hog pancreatic elastase preparation which could be activated by the leukocyte protease.

To distinguish between these two alternative suggestions, the following experiment was done. Several vials of the commercial elastase were pooled and diluted to contain minimally detectable elastase activity in a 
$100-\mu 1$ sample. The diluted commercial sample was then mixed with between 0.6 and $60 \mu \mathrm{g}$ of the leukocyte extract and the mixture assayed for elastase activity. Simultaneously, various concentrations of trypsin $(0.1-$ $100 \mu \mathrm{g}$ ) were also mixed with the elastase preparation and assayed. In addition, each of the reagents were assayed separately, and the trypsin and rat leukocyte extracts also mixed and assayed. The results are shown in Table 3. It can be seen clearly that both the rat leukocyte extract as well as the crystalline trypsin greatly potentiated the elastase activity of the commercial hog pancreatic elastase preparation. It can also be seen that the leukocyte extract was much more effective than the trypsin. Six micrograms of the leukocyte extract (with hemoglobin-hydrolyzing activity equivalent to $0.08 \mu \mathrm{g}$ of trypsin) produced as much activation as $100 \mu \mathrm{g}$ of the pure trypsin. It can also be seen in Table 3 that when the leukocyte extract and the trypsin were incubated together, there was no evidence of enhanced elastase activity. The results shown in Table 3 were obtained using the synthetic elastase substrate. Similar results were also obtained with the protein substrates.

Table 3. Activation of Latent Elastase Activity in Hog Pancreatic Elastase Preparation ${ }^{a}$

\begin{tabular}{lc}
\hline \multicolumn{1}{c}{$\begin{array}{c}\text { Enzyme } \\
\text { combination }\end{array}$} & $\begin{array}{c}\text { Activity } \\
\left(\mathrm{OD}_{410} \pm S E M\right)\end{array}$ \\
\hline Saline & $0.027 \pm 0.008$ \\
Saline $+0.1 \mu \mathrm{g} \mathrm{HPE} \mathrm{HP}^{b}$ & $0.046 \pm 0.010$ \\
Saline $+100 \mu \mathrm{g}$ trypsin & $0.030 \pm 0.011$ \\
Saline $+60 \mu \mathrm{g} \mathrm{RLE}$ & \\
Saline $+6.0 \mu \mathrm{g} \mathrm{RLE}$ & $0.092 \pm 0.017$ \\
Saline $+0.6 \mu \mathrm{g}$ RLE & $0.030 \pm 0.009$ \\
$60 \mu \mathrm{g}$ RLE + saline & $0.030 \pm 0.008$ \\
$60 \mu \mathrm{g}$ RLE $\pm 100 \mu \mathrm{g}$ trypsin & $0.035 \pm 0.007$ \\
$6 \mu \mathrm{g}$ RLE + saline & $0.025 \pm 0.001$ \\
$6 \mu \mathrm{g}$ RLE $+100 \mu \mathrm{g}$ trypsin & $0.005 \pm 0.001$ \\
$100 \mu \mathrm{g}$ trypsin $+0.1 \mu \mathrm{g} \mathrm{HPE}$ & $0.005 \pm 0.002$ \\
$10 \mu \mathrm{g}$ trypsin $+0.1 \mu \mathrm{g} \mathrm{HPE}$ & $0.873 \pm 0.040$ \\
$1.0 \mu \mathrm{g}$ trypsin $+0.1 \mu \mathrm{g} \mathrm{HPE}$ & $0.492 \pm 0.029$ \\
$0.1 \mu \mathrm{g}$ trypsin $+0.1 \mu \mathrm{g} \mathrm{HPE}$ & $0.220 \pm 0.017$ \\
$60 \mu \mathrm{g}$ RLE $+0.1 \mu \mathrm{g} \mathrm{HPE}$ & $0.063 \pm 0.011$ \\
$6.0 \mu \mathrm{g}$ RLE $+0.1 \mu \mathrm{g} \mathrm{HPE}$ & $0.993 \pm 0.038$ \\
$0.6 \mu \mathrm{g}$ RLE $+0.1 \mu \mathrm{g} \mathrm{HPE}$ & $0.859 \div 0.051$ \\
\hline
\end{tabular}

\footnotetext{
${ }^{a}$ The assay was carried out as described in the Materials and Methods section. The various reagents were mixed together and incubated at $37^{\circ} \mathrm{C}$ for $30 \mathrm{~min}$ along with the substrate, succinyl-alanyl-alanyl-alanine-p-nitroanilide.

${ }^{b}$ HPE $=$ hog pancreatic elastase.

${ }^{c}$ RLE = rat leukocyte extract (hemoglobin-hydrolyzing activity equivalent to $0.8 \mu \mathrm{g}$ of trypsin).
} 
The activation of the latent activity could be detected in both the hemoglobin-hydrolysis assay and the $\left[{ }^{14} \mathrm{C}\right]$ elastin-hydrolysis assay.

\section{DISCUSSION}

Human polymorphonuclear leukocytes contain large amounts of neutral proteases. These potent degradative enzymes have the ability to attack a variety of protein substrates $(3,5,6,19-23)$ and are thought to play active roles in a number of pathological processes. Human leukocyte elastase, in particular, has been linked to both arthritis and emphysema because of its ability to degrade proteoglycans and elastin fibers (3, 24-27). Analogous enzymes to those found in human neutrophils have been identified in the granulocytes from various species, but it is apparent that a considerable amount of species-dependent differences exist (7-12). If animal models are to be successfully used in efforts to delineate the mechanisms of various pathological processes that are thought to be protease-mediated, it is imperative that these species-dependent differences be taken into account. In this report we describe functionally the neutral protease activity obtained from rat leukocytes.

High levels of protease activity were detected in whole-cell preparations and in isolated granules. When compared to crystalline bovine pancreatic trypsin with regard to hemoglobin-hydrolyzing activity, $60 \mu \mathrm{g}$ of the rat leukocyte extract had activity equal to approximately $0.8 \mu \mathrm{g}$ of trypsin. Three other proteins (i.e., albumin, fibrinogen, and a partially purified basement membrane preparation) were also readily hydrolyzed by the leukocyte protease. In contrast, native elastin and the synthetic elastase substrate $N$-succinyl-alanyl-alanyl-alanine-p-nitroanilide proved to be very resistant to leukocyte extract-induced hydrolysis under the conditions tested.

In many respects the rat protease is similar to the neutral proteases obtained from the leukocytes of other mammalian species. For example, optimal activity (in the hemoglobin-hydrolysis assay and in the elastase assays) is obtained at pH $8(8,12)$. Furthermore, both activities are susceptible to inhibition by SBTI, LBTI, and TPCK but are resistant to inhibition by TLCK, pepstatin, and leupeptin $(9,12)$. Whether or not the two activities are the result of a single enzyme or the result of two separate enzymes cannot be determined with the presently available data. The answer to that question will have to await purification studies. The object of the present study was not to chemically characterize the enzyme(s) responsible for these activities but to point out the fact that, unlike the human leukocytes, the rat cells contain a high level of protease activity but native elastin 
and synthetic elastase substrates are relatively resistant to it. This finding must be taken into account when the rat is used as a model for the study of disease processes that are thought to be mediated by proteolytic enzymes, particularly elastase. Perhaps the low level of elastase activity explains why rats are unusually resistant to emphysema-like conditions.

A very interesting observation made during the course of this study relates to the activation of latent elastase activity in the commercial elastase preparation by the rat granulocyte protease. The activation phenomenon was initially identified during attempts to determine if the granulocytes contained factors inhibitory to elastase. Cytosolic protease inhibitors in human leukocytes have been previously identified (28). Not only did the rat leukocyte extract not inhibit the hog pancreatic elastase but rather, greatly potentiated it. Although the activation mechanism is unknown, it could involve a proteolytic modification of a "proelastase" molecule since trypsin also demonstrated elastase activating activity. The activation of a proelastase molecule could be analogous to the process by which latent collagenolytic enzymes are activated $(30,31)$. Although both the rat leukocyte protease and crystalline trypsin potentiated the activity in the commercial elastase preparation, the rat leukocyte extract appeared to be much more efficient than the trypsin. Six micrograms of the leukocyte extract (with hemoglobinhydrolyzing activity equivalent to $0.08 \mu \mathrm{g}$ of trypsin) produced the same amount of activation as $100 \mu \mathrm{g}$ of trypsin.

The ability of rat leukocyte protease to activate latent elastase may provide a mechanism whereby active elastase could be generated at sites of chronic inflammation. One could postulate, for example, that if a proelastase were being released at sites where substantial numbers of the granulocytes were simultaneously present, the activity of the granulocyte protease would quickly convert the proenzyme into the active form. The likely candidate cell for the source of the proelastase would be the macrophage. This may be a moot point, however, since very recent work seems to indicate that rat macrophages, unlike those from other species, are also specifically devoid of elastase (32). It may be that all of the inflammatory cells of the rat have relatively low levels of elastase or elastase-like enzymes. If this turns out to be the case, the rat may be a good model in which to examine the role of nonelastolytic neutral proteases in various pathological processes.

\section{REFERENCES}

1. Rindler, R., F. Schmalzl, H. Hortnagel, and H. Braunsteiner. 1971. Naphthol AS-D chloroacetate esterases in granule extracts from human neutrophil leukocytes. Blut 23:223-227. 
2. Rindler-Ludwig, R., and H. Braunsteiner. 1975. Cationic proteins from human neutrophil granulocytes. Evidence for their chymotrypsin-like properties. Biochim. Biophys. Acta 379:606-617.

3. JANOFF, A., and J. Scherer. 1968. Mediators of inflammation in leukocyte lysozomes. IX. Elastinolytic activity in granules of human polymorphonuclear leukocytes. J. Exp. Med. 128:1137-1155.

4. JANOFF, A. 1969. Alanine p-nitrophenyl esterase activity of human leukocyte granules. Biochem. J. 114:157-159.

5. Lazarus, G. S., R. S. Brown, J. R. Daniels, and H. M. Fullmer. 1968. Human granulocyte collagenase. Science 159:1483-1485.

6. Lazarus, G. S., J. R. Daniels, R. S. Brown, H. A. Bladen, and H. M. Fullmer. 1968. Degradation of collagen by a human granulocyte collagenolytic system. J. Clin. Invest. 47:2622-2629.

7. Davies, P., G. A. Rita, K. Krakauer, and G. Weissmann. 1971. Characterization of a neutral protease from lysozomes of rabbit polymorphonuclear leukocytes. Biochem $J$. 123:559-569.

8. ANDERSON, A. J., and C. IRWIN. 1973. Some properties of neutral-acting and other degredative enzymes in rat leukocytes. Life Sci. 13:601-612.

9. Ardelt, W., Z. Tomczak, S. Ksiezny, and G. Dudek-Wojciechowska. 1976. Neutral elastolytic proteinase from canine leukocytes: Purification and characterization. Biochim. Biophys. Acta 445:683-693.

10. Dubin, A., A. KoJ, and J. Chudzik. 1976. Isolation and some molecular parameters of elastase-like neutral proteinases from horse blood leukocytes. Biochem. J. 153:389-396.

11. KoJ, A., J. ChuDzIK, and A. Durin. 1976. Substrate specificity and modification of the active center of elastase-like neutral proteinases from horse blood leukocytes. Biochem. $J$. 153:397-402.

12. Vassalli, J. D., A. Granelli-Piperno, C. Griscelli, and E. Reich. 1978. Specific protease deficiency in polymorphonuclear leukocytes in Chediak-Higashi syndrome and beige mice. J. Exp. Med. 147:1285-1290.

13. CoHN, Z. A., and S. I. MoRse. 1959. Interactions between rabbit polymorphonuclear leukocytes and staphylocci. J. Exp. Med. 110:419-443.

14. KAPLAN, J., and M. L. NikLson. 1979. Analysis of macrophage surface receptors. J. Biol. Chem. 254:7329-7335.

15. Varani, J., K. Johnson, and J. Kaplan. 1980. Development of a solid-phase assay for measurement of proteolytic enzyme activity. Anal. Biochem. 107:377-384.

16. JOHNSON, K. J., and J. VARANI. 1981. Substrate hydrolysis by immune complex-activated neutrophils: Effect of physical presentation of complexes and protease inhibitors. $J . \mathrm{Im}^{\mathrm{m}}$ munol. 127:1875-1879.

17. Bray, B. A., and F. C. LeRAy. 1976. Human alveolar basement membrane. Chemical and immunologic comparisons with glomerular basement membrane and trophoblast basement membrane. Microvasc. Res. 128:77-89.

18. BIETH, J., B. SPIESS, and C. G. WERMUTH. 1974. The synthesis and analytical use of a highly sensitive and convenient substrate of elastase. Biochem. Med. 11:350-357.

19. Movat, H. Z., S. G. Steinberg, F. M. Habol, and N. S. Ranadive. 1973. Demonstration of a kinin-generating enzyme in the lysosomes of human polymorphonuclear leukocytes. Lab. Invest. 29:669-684.

20. Venge, P., and I. Olsson. 1975. Cationic proteins of human granulocytes. VI. Effects on the complement system and mediation of chemotactic activity. J. Immunol. 115:15051508.

21. Plow, E. F., and T. S. Edgington. 1975. An alternative pathway for fibrinolysis. I. The cleavage of fibrinogen by leukocyte proteases of physiologic pH. J. Clin. Invest. 56:30-38. 
22. Solomon, A., W. Schmidt, and K. Havemann. 1976. Bence Jones proteins and light chains of immunoglobulins. XIII. Effect of elastase-like and chymotrypsin-like neutral proteases derived from human granulocytes on Bence Jones proteins. J. Immunol. 117: 1010-1014.

23. JANOFF, A., and J. D. Zeligs. 1968. Vascular injury and lysis of basement membranes in vitro by neutral proteases of human leukocytes. Science 161:702-704.

24. Keiser, H., R. A. Greenwald, G. FeinsteIn, and A. Janoff. 1976. Degredation of cartilage proteoglycan by human leukocyte granule neutral protease-a model for joint injury: Degredation of isolated bovine nasal cartilage proteoglycans. J. Clin. Invest. 57:625-632.

25. Ignarro, L. J., A. L. Oronsky, and R. J. Perper. 1973. Breakdown of noncollagenous chondromucoprotein matrix by leukocyte lysozome granule lysates from guinea pig, rabbit and human. Clin. Immunol. Immunopathol. 2:36-51.

26. JANOFF, A. 1975. At least three human neutrophil lysosomal proteases are capable of degrading joint connective tissue. Ann. N. Y. Acad. Sci. 256:402-408.

27. Kaplan, P. D., C. KunN, and J. A. PierCE. 1973. The induction of emphysema with elastase I. The evaluation of the lesion and the influence of serum. J. Lab. Clin. Med. 82:349359.

28. JANOFF, A., and J. BLondin, 1971. Inhibition of the elastase-like esterase in human leukocyte granules by human leukocyte cell sap. Proc. Soc. Exp. Biol. 136:1050-1053.

29. JANOFF, A., and J. BLoNDIN. 1971. Further studies on an esterase inhibitor in human leukocyte cytosol. Lab. Invest. 25:565-571.

30. Bierkedal-Hansen, H., C. M. Cobb, R. E. Taylor, and H. M. Fullmer. 1975. Trypsin activation of latent collagenase from several mammalian sources. Scand. J. Dent. Res. 83: 302-305.

31. Oronsky, A. L., R. J. Perper, and H. C. Schroder. 1973. Phagocytic release and activation of human leukocytes procollagenase. Nature 246:417-419.

32. Goodrun, K. J., and J. K. SPITzNAGEL. 1981. Comparison of neutral protease secretion from mouse and rat peritoneal macrophages. Program and Abstracts of the Eighteenth Annual Meeting of the Reticuloendothelial Society (held Oct. 12-16, 1981; Milwaukee, Wisconsin) 9 a. 